\title{
Aplikasi Pendekatan Theory of Constraints pada Maksimasi Throughput Produksi
}

\section{PT XYZ}

\author{
Leo Rama Kristiana ${ }^{1}$, Theresia Sunarni ${ }^{2}$ \\ ${ }^{1}$ Institut Teknologi Harapan Bangsa penulis \\ Jl. Dipati Ukur No 80-84 Kota Bandung \\ ${ }^{1}$ leorama@ithb.ac.id \\ ${ }^{2}$ Universitas Katolik Musi Charitas \\ Jalan Bangau No. 60 Palembang \\ ${ }^{2}$ nani_ys@yahoo.com
}

Dikirimkan: 08, 2018. Diterima: 09, 2018. Dipublikasikan: 10,2018.

\begin{abstract}
PT XYZ is a manufacturing company that produces various furniture products. The company has two product categories, first category A (as standard products) with production system is make to stock the second is category $B$ (custom products) with production system is make to order. The problem of production will be arise when face high demand. Limitations of production's resources cause bottleneck in lines production and inability to meet demand. In addition, inaccuracies in allocating limited resources will causing descent of throughput. Resource with the biggest gap between needs and availability, and to be causes bottleneck condition known as constraints. The maximum throughput can be achieved by optimizing the constraints. This research was conducted to identify the limitations of resources that become constarints in achieving maximum throughput. Theory of Constraints (TOC) is used as a problem solving approach. The TOC approach is used to identify production resources that are constraints in meeting demand and achieving maximum throughput. Problem of constraints optimization to achieve maximum throughput are modeled in the form of linear programming problems. The result of constraint optimization is the number of each type of product that must be produced at the existing capacity and the maximum total throughput that can be achieved. The TOC approach is the basis in determining the solution of limited resources so that all demand can be met. Data processing concludes that the production resources that become constraints are man power and man hours operators. Optimization of regular resources reaches a maximum throughput at $R p$ 819,148,490, with the demand for A-101 and A-104 products cannot be met entirely. Production capacity can be increased by several alternatives, such as: overtime hours, day laborers, production sub-contracts, recruitment of new operators, and combinations thereof. The most optimal alternative is a combination of new operator recruitment and overtime. This alternative increases throughput by $22.40 \%$.
\end{abstract}

Key word__ _ throughput; constraints; theory of constraints

Abstrak- PT XYZ merupakan perusahaan manufaktur yang memproduksi beraneka ragam produk funiture. Perusahaan ini memiliki dua kategori produk, yaitu kategori A (produk standar) dengan sistem produksi make to stock dan kategori B (custom product) dengan sistem produksi make to order. Produk kategori A memiliki 10 (sepuluh) tipe produk, dan 4 (empat) diantaranya merupakan produk unggulan. Permasalahan produksi PT XYZ timbul ketika menghadapi demand yang tinggi. Keterbatasan resource produksi menyebabkan terjadinya bottleneck pada lintasan produksi dan ketidakmampuan memenuhi demand. Selain itu, ketidak tepatan dalam mengalokasikan resource yang terbatas berpotensi menurunkan throughput. Resource yang memiliki ketersediaan terkecil dan menjadi penyebab bottleneck dalam mencapai throughput maksimal dikategorikan sebagai constraints. Titik throughput maksimal dapat dicapai dengan mengoptimalkan constraints. Penelitian ini dilakukan untuk mengidentifikasi keterbatasan sumber daya (resources) yang menjadi constarints dalam pencapaian throughput maksimal. Theory of Constraints (TOC) digunakan sebagai pendekatan penyelesaian masalah. Pendekatan TOC digunakan untuk mengidentifikasi resource produksi yang menjadi constraints dalam pemenuhan demand. Permasalahan optimasi constraints untuk mencapai throughput maksimal dimodelkan dalam bentuk permasalahan programa linier. Hasil dari 
optimasi constraint adalah jumlah tiap jenis produk yang harus diproduksi pada kapasitas eksisting dan total throughput maksimal yang dapat dicapai. Pedekatan TOC menjadi dasar dalam mentukan solusi keterbatasan sumber daya sehingga seluruh demand dapat dipenuhi. Hasil pengolahan data menyimpulkan resource produksi yang menjadi constraints adalah man power dan man hours tenaga kerja. Optimalisasi terhadap sumber daya reguler menghasilkan throughput maksimum sebesar Rp 819.148.490 dengan demand produk A-101 dan A-104 tidak dapat dipenuhi seluruhnya. Penambahan kapasitas produksi dapat dilakukan dengan beberapa alternatif, yakni: jam lembur, buruh lepas, sub kontrak produksi, penambahan jumlah tenaga kerja dan kombinasinya. Throughput maksimal diperoleh dari alternatif kombinasi antara penambahan jumlah tenaga kerja reguler dan jam over time dengan peningkatan throughput sebesar $22,40 \%$.

Kata kunci- throughput; constraints; theory of constraints

\section{PENDAHULUAN}

Theory of constraints (TOC) diartikan sebagai suatu pendekatan ke arah peningkatan proses yang berfokus pada elemen-elemen yang dibatasi untuk meningkatkan output [1]. Awalnya TOC digunakan untuk melakukan merencanakan sumber daya produksi, dan terus dikembangkan seiring dengan perkembangan teknologi, bentuk dan hubungan industri serta persaingannya [2]. Penggunaan TOC dalam merencanakan kegiatan produksi tetap relevan digunakan, khususnya untuk perencanaan yang berkaitan dengan keterbatasan sumber daya (resource).

Perencanaan produksi dilakukan untuk menjamin kelancaran proses produksi guna pemenuhan tujuan yang ingin dicapai. Tantangan yang dihadapi dalam kegiatan produksi sama seperti yang dihadapi dalam kegiatan ekonomi, begitu juga dengan tujuan yang ingin dicapai, yakni peningkatanan layanan, penurunan biaya (the reduction of cost), dan meningkatkan kepuasan pelanggan [3]. Theory of constraints (TOC) memiliki prespektif bahwa semua organisasi memiliki tujuan akhir yang ingin dicapai, goal yang terukur, dari setiap elemen organisasi yang terhubung, dan dalam proses pencapaiannya terdapat keterbatasan (constraints) dari sejumlah faktor yang dapat menyebabkan penundaan atau kemacetan yang dikenal dengan istilah bottleneck [3].

PT XYZ adalah perusahaan manufaktur yang memproduksi furniture. Produk diklasifikasikan berdasarkan sistem produksinya, yaitu make to stock yang merupakan produk standar atau kategori A, dan make to order atau di produksi by request dikelompokkan pada produk kategori $\mathrm{B}$. Pemenuhan permintaan konsumen dapat dilakukan apabila perusahaan memiliki perencanaan produksi yang baik. Dalam perencanaan produksi ada beberapa hal yang harus diperhatikan, seperti sistem lintasan produksi yang seimbang, perhitungan kapasitas produksi serta integrasinya antar kapasitas stasiun kerja dan sistem ketenaga-kerjaan. Ketiga hal tersebut adalah resource yang dibutuhkan dalam menghasilkan throughput maksimal. Resource yang memiliki kapasitas terkecil berpotensi menimbulkan bottleneck, dan akan dikategorikan sebagai constraints.

Keterbatasan resource dioptimalkan dengan memilih jenis produk yang memiliki throughput maksimal untuk diproduksi. Kekurangan resource membuat sejumlah demand dari beberapa produk tidak dapat dipenuhi oleh kapasitas produksi eksisting. Apabila kapasitas perusahaan tidak dapat memenuhi demand menggunakan kapasitas resources eksisting, perusahaan dapat meningkatkan kapasitas resource eksisting atau menggunakan alternative resource non-reguler. Resource non-reguler dapat berupa jam lembur (over time), buruh harian lepas (out sourcing operator), dan sub kontrak produksi. Kesalahan penentuan produksi dan penentuan pemenuhan resource membuat throughput sebagai keuntungan perusahaan menurun. Identifikasi constraints dari resources dan elemen throughput dilakukan menggunakan pendekatan Theory of Constraints (TOC). Permasalahan optimalisasi constraints dengan tujuan maksimasi throughput dilakukan menggunakan metode programa linier.

Tujuan yang ingin dicapai dalam penelitian ini untuk mengidentifikasi bottleneck resource sehingga sistem dapat mencapai throughput produksi yang maksimal. Throughput produksi mencerminkan tingkat profitabilitas produksi. Profitabilitas didapatkan dengan melakukan optimalisasi penggunaan resource yang ada dan kemampuan untuk meningkatkan efisiensi proses. [3]. Dengan demikian perlu untuk diketahui resource yang menjadi constraints, pengaturan produksi untuk tiap jenis produk, dan menentukan cara pemenuhan demand pada kapasitas eksisting terpasang dan strategi peningkatan kapasitas yang dapat digunakan. Pada penelitian ini berfokus pada empat jenis produk kategori-A dan resource produksi.

\section{Metodologi Penelitian}

\section{A. Definisi dan Prinsip Theory of Constraints}


Teori Kendala atau theory of constraints (TOC) merupakan sebuah filosofi manajemen yang mula-mula dikembangkan oleh Eliyahu $\mathrm{M}$. Goldratt dan dikenalkan dalam bukunya, The Goal Theory of Constraintss [1]. TOC dapat diartikan juga sebagai pendekatan manajemen yang berfokus pada eliminasi proses bottleneck dilakukan secara terus menerus untuk meningkatan peforma proses manufaktur [4]. Pendekatan TOC memiliki beberapa konsep, antara lain proses berpikir TOC, lima langkah TOC, sembilan langkah optimized production technology (OPT), dan drum-buffer-rope schedulling. Pendekatan ini digunakan untuk menjawab tiga pertanyaan dasar, yaitu: apa yang dirubah/perbaiki (what to change); dirubah/diperbaiki menjadi seperti apa (to what to change to); dan bagaimana membuat perubahan/ perbaikan (how cause the change) [4].

Setiap perusahaan secara langsung memiliki keterbatasan dalam mencapai tujuannya. Segala sesuatu sumber daya yang terbatas dapat disebut dengan constraints. Terdapat enam variable sebagai ukuran perusahaan atau organisasi mencapai tujuannya. Variable ini bagi menjadi dua kelompok, yaitu kelompok operasional: throughput, inventory, biaya operasional; dan kelompok finansial: laba bersih, pengembalian investasi, dan arus kas [5].

TOC sebagai pendekatan manajemen dalam mengalokasikan sumber daya yang terbatas untuk mencapai tujuan perusahaan. Pendekatan ini bekerja dengan meningkatkan keuntungan dengan memaksimalkan throughjput produksinya dan meminimalisasi semua ongkos atau biaya yang relevan seperti biaya simpan, biaya langsung, biaya tidak langsung, dan biaya modal. Penerapan TOC lebih terfokus pada pengelolaan operasi yang berkendala sebagai kunci dalam meningkatkan kinerja sistem produksi, nantinya dapat berpengaruh terhadap profitabilitas secara keseluruhan.

Sedangkan menurut Gunadi [6] constraints adalah segala hal dalam perusahaan yang membatasinya untuk mencapai tujuannya. Adapun kendala yang timbul dapat terletak pada kapasitas mesin dan kemampuan tenaga kerja yang dimiliki oleh perusahaan. Ketepatan waktu dan kualitas bahan baku yang dikirim supplier dapat juga menjadi kendala, sehingga seringkali target produksi kurang dapat tercapai. Teori ini memfokuskan diri pada tiga ukuran yaitu [7]:

a) Throughput, adalah suatu ukuran dimana suatu perusahaan menghasilkan uang melalui penjualan.

b) Persediaan, adalah semua dana yang dikeluarkan perusahaan untuk mengubah bahan baku mentah melalui throughput. Bahan persediaan dalam TOC merupakan semua aktiva yang dimiliki dan tersedia secara potensial untuk penjualan.

c) Biaya-biaya operasional, yang dikeluarkan perusahaan untuk mengubah persediaan menjadi throughput. Biaya operasi ini terjadi untuk mendukung dan mengoptimalkan throughput dalam kendala.

Bentuk constraints pada sistem dapat dikelompokkan menjadi physical dan non physical constraintss [12]. Constraints harus diklasifikasikan berdasarkan bagaimana mengelolanya [8]. Terdapat beberapa bentuk constraints, seperti kapasitas, ketersediaan bahan baku, kondisi politik, market, infrastruktur, logistik, metode kerja, tingkah laku, administrasi, dan sumber daya manusia.

Theory of Constraints memiliki lima langkah penyelesaian masalah yang dikemukakan oleh Goldratt [7]. Lima langkah tersebut adalah:

1) Identifikasi constraints dalam sistem. Tahap awal ini dilakukan dengan melihat kelemahan sistem yang menjadi kendala pengoptimalan. kelemahan yang ada selanjutnya dikelompokan berdasarkan kelemahan fisik atau kelemahan kebijakan.

2) Eksploitasi constraints (exploiting the constraints), menentukan bagai mana cara melakukan eksploitasi batasan atau constraints dengan menggunakan biaya yang efisien.

3) Subordinasi sumber lainnya (subordinating the remaining resources), setelah menentukan constraints dan memutuskan cara pengelolahannya maka langkah selanjutnya adalah mengevaluasi apakah constraints tersebut masih menjadi kendala pada performansi sistem atau tidak. Jika tidak maka akan menuju langkah kelima, tetapi jika ya akan menuju langkah keempat.

4) Evaluasi constraints (elevating the constraints), jika langkah ini dilakukan maka langkah kedua dan ketiga tidak berhasil menangani konstrain. Maka harus ada perubahan di dalam sistem, dapat berupa reorganisasi, perbaikan lintasan produksi, perbaikan modal atau modifikasi subtansi sistem.

5) Mengulangi proses keseluruhan (repeating the process). Jika langkah ketiga dan keempat telah berhasil dilakukan maka akan mengulangi lagi dari langkah pertama. Proses ini akan berputar sebagai siklus. Penyelesaian yang dilakukan pada langkah 
empat akan memiliki kemungkinan untuk menimbulkan constraints baru.

Pendekatan TOC memiliki beberapa asumsi yang digunakan. Asumsi yang biasanya digunakan pada penelitian-penelitian TOC antanya, yaitu [8]:

1) Tujuan utama dari perusahaan atau organisasi adalah mendapatkan keuntungan yang maksimal;

2) Biaya tenaga kerja langsung dianggap sebagai biaya operasional;

3) Setidaknya terdapat satu batasan atau kendala (constraints) pada setiap produk yang menghalangi perusahaan dalam mencapai tujuan utama. Kendala ini dapat berasal dari internal ataupun eksternal organisasi; dan,

4) Selalu ada kesulitan dalam menyusun rencana aliran produk di rantai pasoknya.

TOC sebagai pendekatan manajemen keseluruhan (wide global view) suatu organisasi dapat digunakan pada sub-sistem yang kecil dan spesifik, asalkan tujuan yang dicapai merupakan bagian dari tujuan manajemen global organisasinya [11]. Secara umum tujuan global dari manajemen PT XYZ adalah maksimasi profitabilitas dan profit. Pendekatan TOC digunakan pada sub sistem produksi dengan tujuan akhir peningkatan throughput direpresentasikan sebagai total kapasitas produksi dan total profit. Prinsip TOC sekilas akan terlihat bertentangan dengan pendekatan perbaikan lain, yang ditujukan untuk mengoptimasi peformance di setiap bagian area sistem, TOC memiliki dasar pemikiran bahwa meningkatkan peformansi keseluruhan sistem berawal dengan fokus pada penyelesaian kritikal komponen pada sistem [11].

\section{B. Metodologi Penelitian}

Penelitian diselesaikan melalui IV tahapan, seperti diagram alir pada Gambar 1.

Secara spesifik penelitian ini dilakukan pada objek produk kategori A yaitu produk A-101, A102, A-103 dan A-104. Jenis produk dipilih berdasarkan jumlah demand dan frekuensi lost sales tertinggi diantara produk lainnya.

\section{Pengumpulan dan Pengolahan Data Awal}

Komponen biaya yang dibutuhkan dalam penelitian ini meliputi biaya bahan baku, biaya tenaga kerja, biaya sub kontrak, biaya over head dan harga jual produk. Data komponen biaya yang menajdi input dalam pengolahan data dapat dilihat pada Tabel I.

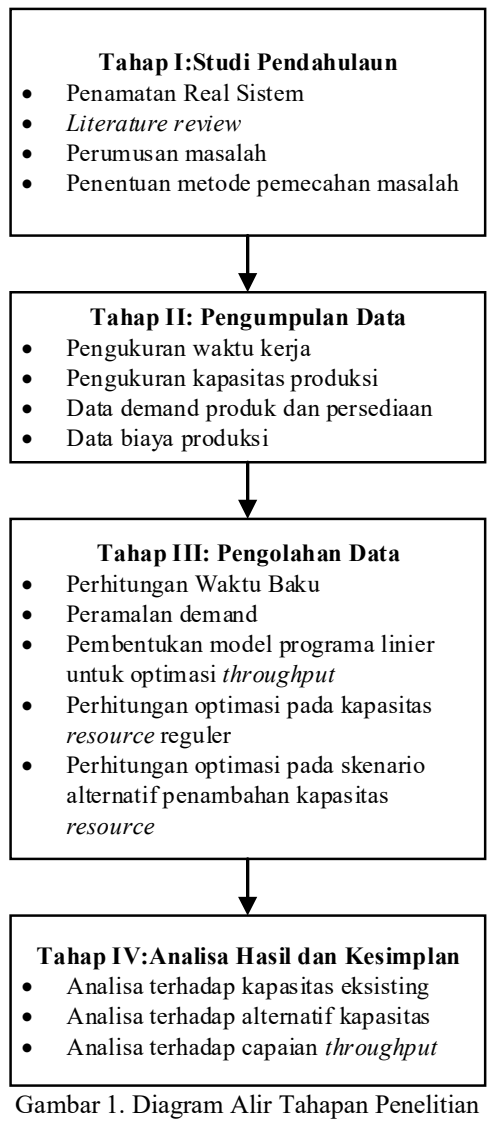

TABEL I

DATA PARAMETER BIAYA DAN HARGA

\begin{tabular}{|c|c|}
\hline Komponen & Jumlah \\
\hline Tenaga Kerja Reguler per hari & Rp 50.000 \\
\hline Tenaga Kerja Overtime per jam & Rp 7.500 \\
\hline \multicolumn{2}{|c|}{ Tenaga Kerja Borongan per Produk } \\
\hline A-101 & Rp 7.500 \\
\hline A-102 & Rp 13.500 \\
\hline A-103 & Rp 11.500 \\
\hline A-104 & Rp 75.000 \\
\hline $\begin{array}{l}\text { Biaya Makan per hari tenaga } \\
\text { kerja borongan }\end{array}$ & Rp 10.0000 \\
\hline Biaya Lepas & Rp 25.000 \\
\hline Biaya overhead* & Rp2.500.000 \\
\hline \multicolumn{2}{|l|}{ Harga Jual per Produk } \\
\hline A-101 & $\mathrm{Rp} 50.000$ \\
\hline A-102 & Rp 155.000 \\
\hline A-103 & Rp 125.000 \\
\hline A-104 & Rp 275.000 \\
\hline \multicolumn{2}{|c|}{ Biaya Produksi dengan Subkontrak per Produk } \\
\hline A-101 & Rp 38.500 \\
\hline A-102 & Rp 125.000 \\
\hline A-103 & Rp 105.000 \\
\hline
\end{tabular}




\begin{tabular}{lcc}
\hline \multicolumn{1}{c}{ Komponen } & Jumlah \\
\hline A-104 & Rp & 210.000 \\
\hline Biaya Bahan Baku per Produk & & \\
\hline A-101 & Rp & 16.500 \\
\hline A-102 & Rp & 42.500 \\
\hline A-103 & Rp & 38.600 \\
\hline A-104 & Rp & 96.000 \\
\hline
\end{tabular}

Untuk mengetahui kebutuhan resource diperlukan data demand produk. Data demand yang digunakan untuk menghitung kebutuhan resource adalah data hasil forecasting dari data permintaan tahun 2016 dan tahun 2017. Metode forecasting dipilih berdasarkan pola data masa lalu. Plotting data demand masa lalu seperti pada Gambar 2 dan Gambar 3.

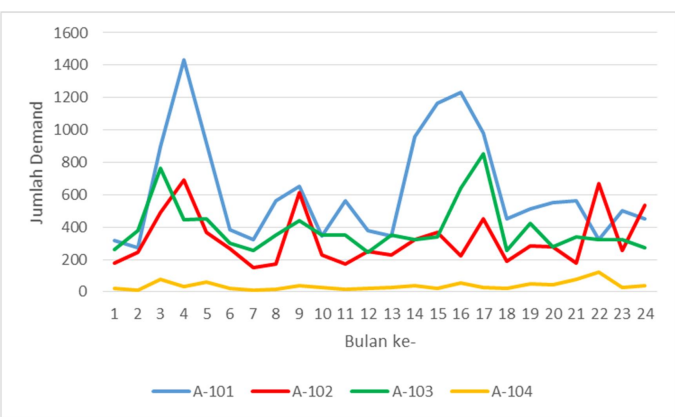

Gambar 2. Plotting Data Demand Masa Lalu Per Produk

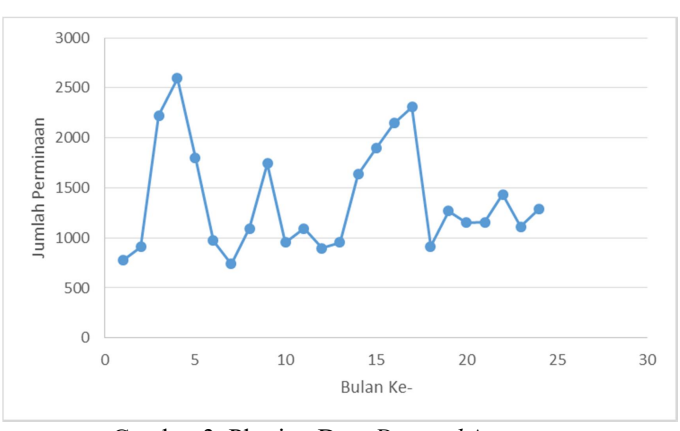

Gambar 3. Plotting Data Demand Agregat

Pola demand pada Gambar 3 membentuk pola musiman. Forecasting dilakukan untuk 12 bulan ke depan dengan menggunakan beberapa metode yang sesuai. Metode forecasting terbaik dipilih berdasarkan nilai mean absolute deviation (MAD) terkecil, yaitu metodeHolt-Winter Additive Algorithm (HWA). Hasil forecasting untuk periode 12 perode ke depan dapat dilihat pada Tabel II.
TABEL II

HASIL FORECASTING DEMAND

\begin{tabular}{ccccc}
\hline $\begin{array}{c}\text { Bln } \\
\text { ke- }\end{array}$ & A-101 & A-102 & A-103 & A-104 \\
\hline 1 & 678 & 338 & 438 & 40 \\
\hline 2 & 691 & 344 & 446 & 41 \\
\hline 3 & 704 & 350 & 455 & 42 \\
\hline 4 & 717 & 357 & 463 & 43 \\
\hline 5 & 730 & 363 & 471 & 43 \\
\hline 6 & 743 & 370 & 480 & 44 \\
\hline 7 & 756 & 376 & 488 & 45 \\
\hline 8 & 768 & 382 & 496 & 46 \\
\hline 9 & 781 & 389 & 504 & 46 \\
\hline 10 & 794 & 395 & 513 & 47 \\
\hline 11 & 807 & 402 & 521 & 48 \\
\hline 12 & 820 & 408 & 529 & 49 \\
\hline
\end{tabular}

Proses produksi produk A-101, A-102, A-103 dan A-104 dilakukan di 4 (empat) stasiun kerja, yaitu Stasiun Kerja (SK) ke-1 untuk proses pemotongan, SK ke-2 untuk proses pembentukan komponen/part, SK ke-3 untuk proses perakitan (assembly) komponen/part dan SK ke-4 untuk proses finishing. Data waktu proses setiap produk pada keempat stasiun kerja diperoleh dari hasil pengukuran waktu kerja dengan menggunakan metode direct stop-watch time study dengan menambahkan faktor penyesuaian (performance rating) dan faktor kelonggaran (allowance). Faktor penyesuaian dihitung menggunakan metode penilaian Westing House, sedangkan faktor kelonggaran disesuaikan dengan kondisi real pada area kerja. Hasil pengukuran akan ditetapkan sebagai waktu baku pengerjaan produk. Hasil perhitungan dapat dilihat pada Tabel III.

TABEL III DATA WAKTU PRODUKSI

\begin{tabular}{|c|c|c|c|c|c|}
\hline Produk & SK & $\bar{x}$ & Wn & Ws & Total \\
\hline \multirow{4}{*}{ A-101 } & 1 & 10,38 & 10,17 & 12,33 & \multirow{4}{*}{85,72} \\
\hline & 2 & 8,78 & 9,04 & 11,10 & \\
\hline & 3 & 25,73 & 27,02 & 30,88 & \\
\hline & 4 & 25,73 & 27,02 & 31,41 & \\
\hline \multirow{4}{*}{ A-102 } & 1 & 18,56 & 18,19 & 22,05 & \multirow{4}{*}{121,46} \\
\hline & 2 & 10,06 & 10,36 & 12,71 & \\
\hline & 3 & 50,25 & 52,76 & 60,30 & \\
\hline & 4 & 21,62 & 22,70 & 26,40 & \\
\hline \multirow{4}{*}{ A-103 } & 1 & 15,6 & 15,29 & 18,53 & \multirow{4}{*}{105,81} \\
\hline & 2 & 10,34 & 10,65 & 13,07 & \\
\hline & 3 & 39,48 & 41,45 & 47,38 & \\
\hline & 4 & 21,98 & 23,08 & 26,84 & \\
\hline \multirow{4}{*}{ A-104 } & 1 & 49,24 & 48,26 & 58,49 & \multirow{4}{*}{414,31} \\
\hline & 2 & 35,89 & 36,97 & 45,36 & \\
\hline & 3 & 218,58 & 229,51 & 262,30 & \\
\hline & 4 & 39,45 & 41,42 & 48,17 & \\
\hline
\end{tabular}


Waktu produksi yang digunakan untuk menghitung kebutuhan kapasitas produksi merupakan data waktu standar yang dihitung menggunakan persamaan pada [10], yaitu:

$$
\begin{gathered}
W n=\bar{x}\left(\bar{x} \times p_{f}\right) \\
W s=W n+\frac{100 \%}{100 \%-a}
\end{gathered}
$$

Dimana:

$$
\begin{array}{ll}
\bar{x} & : \text { rata-rata waktu terukut } \\
W n & : \text { waktu normal } \\
W s & \text { : waktu standar } \\
p_{f} & : \text { faktor penyesuaian } \\
a & \text { : persentasi allowance }
\end{array}
$$

Total waktu produksi ditentukan oleh kecepatan kerja tenaga kerja. Data kapasitas mesin dan kapasitas man hour yang tersedia selama proses pengamatan seperti pada Tabel IV.

TABLE IV

KAPAsitas RESOURCE PRODUKSI EKSISTING

\begin{tabular}{ccc}
\hline $\begin{array}{c}\text { Stasiun } \\
\text { Kerja }\end{array}$ & Keterangan & $\begin{array}{c}\text { Kapasitas Per Hari } \\
\text { (dalam menit) }\end{array}$ \\
\hline \multirow{2}{*}{ SK1 } & Man hour & 840 \\
\cline { 2 - 3 } & Mesin 1 & 2400 \\
\cline { 2 - 3 } & Mesin 2 & 2880 \\
\hline \multirow{2}{*}{ SK2 } & Man hour & 840 \\
\cline { 2 - 3 } & Mesin 3 & 2400 \\
\hline \multirow{2}{*}{ SK3 } & Mesin 4 & 1440 \\
\cline { 2 - 3 } & Mesin 5 hour & 2520 \\
\cline { 2 - 3 } & Mesin 6 & 4800 \\
\hline \multirow{3}{*}{ SK4 } & Man hour & 2400 \\
\cline { 2 - 3 } & Mesin 7 & 1680 \\
\cline { 2 - 3 } & Mesin 8 & 1440 \\
\hline & & 28800 \\
\hline
\end{tabular}

Kebutuhan kapasitas produksi dihitung bedasarkan hasil forecasting demand untuk 12 periode ke depan dengan mengasumsikan bahwa pola permintaan 12 periode akan mengikuti pola permintaan masa lalu. Kelemahan forecasting berbasis time series untuk titik waktu yang panjang adalah keakuratan. Hasil forcasting akan semakin bias jika panjang waktu perkiraan semakin panjang [9].

Kebutuhan kapasitas 12 bulan ke depan dihitung dengan menggunakan persamaan sebagai berukut:

$$
W_{p t}^{S K}=\sum_{j}^{n}\left(D_{j p} \times t_{i j}\right)
$$

Dimana:

$$
\begin{array}{ll}
W_{p i}^{S K} & : \quad \begin{array}{l}
\text { total kebutuhan kapasitas stasiun } \\
\text { kerja } i \text { di period } p
\end{array} \\
D_{j t} & : \begin{array}{l}
\text { jumlah demand produk tipe } j \\
\text { pada periode } p
\end{array} \\
t_{j i} & : \begin{array}{l}
\text { Kebutuhan waktu produksi } \\
\text { produk } j \text { di stasiun kerja } i
\end{array}
\end{array}
$$

TABEL V

KeBUtUHAN KaPASITAS PRODUKSI (DALAM MENIT)

\begin{tabular}{ccccc}
\hline $\begin{array}{c}\text { Bulan } \\
\text { ke- }\end{array}$ & SK1 & SK 2 & SK 3 & SK 4 \\
\hline 1 & 26282,4 & 19374,3 & 72638,0 & 43915,0 \\
\hline 2 & 26781,2 & 19742,0 & 74016,6 & 44748,5 \\
\hline 3 & 27280,1 & 20109,7 & 75395,3 & 45582,0 \\
\hline 4 & 27778,9 & 20477,4 & 76774,0 & 46415,5 \\
\hline 5 & 28277,7 & 20845,2 & 78152,6 & 47249,0 \\
\hline 6 & 28776,6 & 21212,9 & 79531,2 & 48082,5 \\
\hline 7 & 29275,4 & 21580,6 & 80909,9 & 48916,0 \\
\hline 8 & 29774,3 & 21948,3 & 82288,6 & 49749,5 \\
\hline 9 & 30273,1 & 22316,0 & 83667,2 & 50583,0 \\
\hline 10 & 30771,9 & 22683,8 & 85045,9 & 51416,6 \\
\hline 11 & 31270,8 & 23051,5 & 86424,6 & 52250,0 \\
\hline 12 & 31769,6 & 23419,2 & 87803,2 & 53083,5 \\
\hline
\end{tabular}

\section{Model Optimasi}

Dari data Tabel IV dan Tabel V dapat dilihat kebutuhan kapasitas resource lebih tinggi dibandingkan dengan ketersedian resource. Kondisi ini menyebabkan bottleneck. Constraints yang ingin dioptimalkan terhadap throughput adalah resource yang memiliki gap tertinggi antara ketersediaan dan kebutuhan kapasitas. Stasiun kerja yang mengalami kondisi bottleneck untuk setiap periodenya disajikan pada Tabel VI.

TABEL VI

IDENTIFIKASI KONDISI BOTTLENECK STASIUN KERJA

\begin{tabular}{ccccc}
\hline Bln & SK1 & SK2 & SK3 & SK4 \\
\hline 1 & Bottleneck & Bottleneck & Bottleneck & Bottleneck \\
\hline 2 & Bottleneck & $\begin{array}{c}\text { Non } \\
\text { Bottleneck }\end{array}$ & Bottleneck & Bottleneck \\
\hline 3 & Bottleneck & $\begin{array}{c}\text { Non } \\
\text { Bottleneck }\end{array}$ & Bottleneck & Bottleneck \\
\hline 4 & Bottleneck & $\begin{array}{c}\text { Non } \\
\text { Bottleneck }\end{array}$ & Bottleneck & Bottleneck \\
\hline 5 & Bottleneck & Bottleneck & Bottleneck & Bottleneck \\
\hline 6 & Bottleneck & Bottleneck & Bottleneck & Bottleneck \\
\hline & & & &
\end{tabular}




\begin{tabular}{ccccc}
\hline BIn & SK1 & SK2 & SK3 & SK4 \\
\hline 7 & Bottleneck & Bottleneck & Bottleneck & Bottleneck \\
\hline 8 & Bottleneck & Bottleneck & Bottleneck & Bottleneck \\
\hline 9 & Bottleneck & Bottleneck & Bottleneck & Bottleneck \\
\hline 10 & Bottleneck & Bottleneck & Bottleneck & Bottleneck \\
\hline 11 & Bottleneck & Bottleneck & Bottleneck & Bottleneck \\
\hline 12 & Bottleneck & Bottleneck & Bottleneck & Bottleneck \\
\hline
\end{tabular}

Kondisi bottleneck mengartikan bahwa kapasitas produksi eksisting tidak dapat memenuhi seluruh demand. PT XYZ perlu untuk mengoptimalkan keterbatasan resource yang tersedia agar mencapai titik throughput maksimal. Pemilihan jenis dan jumlah produk yang diproduksi harus mengacu pada total throughput yang dapat diperoleh.

Pengembangan model liner programing digunakan untuk menentukan jenis dan jumlah produk yang didahulukan untuk diproduksi. Fungsi tujuan dari model adalah maksimasi throughput, yaitu total potensi keuntungan dari tiap jenis produk. Fungsi pembatas (constraints) adalah kapasitas resource produksi. Variabel keputusan model adalah jenis dan jumlah produk.

Notasi dan indeks pada model matematis yang digunakan adalah sebagai berikut:

$$
\begin{array}{lll}
Z_{p} & : & \begin{array}{l}
\text { keuntungan maksimum } \\
\text { pada periode } p
\end{array} \\
x_{j p} & : & \begin{array}{l}
\text { jumlah demand produk tipe } j \text { yang } \\
\text { diproduksi di periode } p
\end{array} \\
t_{j i} & : & \text { waktu proses produk } j \text { di stasiun kerja } j \\
C_{i p}^{s k} & : & \text { kapasitas stasiun kerja } i \text { tersedia } \\
D_{j p} & : & \text { total demand produk } j \text { pada periode ke } \\
& & p \\
B_{j} & : & \text { biaya variabel per produk } j \\
H_{j} & : & \text { harga jual produk } j \\
O H_{p} & : & \text { biaya } \text { overhead periode } p \\
S_{j} & : & \text { varibel artifisial }(\text { slack) } \\
i & : & \text { indeks produk }\{1=\mathrm{A}-101 ; 2=\mathrm{A}-102 ; \\
& & 3=\mathrm{A}-103 ; 4=\mathrm{A}-104\} \\
j & : & \text { indeks stasiun kerja }\{i=1,2,3, \ldots, \mathrm{n}\} \\
p & : & \text { indeks periode }\{p=1,2,3, \ldots, 12\} \\
n & : & \text { total jenis produk }
\end{array}
$$

Fungsi tujuan model adalah maksimasi Z

$$
\operatorname{Maks} Z_{p}=\sum_{j=1}^{n}\left(H_{j}-B_{j}\right) x_{j p}-O H_{p}
$$

Dengan fungsi pembatas:

$$
\begin{gathered}
\sum_{j=1}^{n} x_{j p} \cdot t_{i j} \leq C_{i p}^{s k} \\
x_{j p} \leq D_{j p} \\
x_{j p} \geq 0 \\
x_{j p} \in\{\text { bilangan integer }\}
\end{gathered}
$$

Persamaan (5) adalah fungsi pembatas kapasitas resource, Persamaan (6) adalah fungsi pembatas demand sedangkan persamaan (7) adalah fungsi pembatas yang menjaga solusi berada himpunan bilangan non negatif integer. Komputasi model dilakukan menggunakan bantuan perangkat lunak (software) LINGO.

\section{HASIL PENELITIAN}

Hasil komputasi numerik dari model dapat dilihat pada Tabel VII.

TABEL VII

OUTPUT KOMPUTASI MODEL OPTIMASI THROUGHPUT

\begin{tabular}{|c|c|c|c|c|c|}
\hline Per. & $\begin{array}{c}\text { A- } \\
\mathbf{1 0 1}\end{array}$ & $\begin{array}{c}\text { A- } \\
\mathbf{1 0 2}\end{array}$ & $\begin{array}{c}\text { A- } \\
\mathbf{1 0 3}\end{array}$ & $\begin{array}{c}\text { A- } \\
\mathbf{1 0 4}\end{array}$ & $\begin{array}{c}\text { Total } \\
\text { Throughput }\end{array}$ \\
\hline 1 & 114 & 338 & 438 & 40 & $\mathrm{Rp} 66.557 .200$ \\
\hline 2 & 223 & 344 & 446 & 41 & $\mathrm{Rp} 70.323 .900$ \\
\hline 3 & 194 & 350 & 455 & 42 & $\mathrm{Rp} 70.954 .000$ \\
\hline 4 & 164 & 357 & 463 & 43 & $\mathrm{Rp} 71.571 .700$ \\
\hline 5 & 74 & 363 & 471 & 43 & $\mathrm{Rp} 70.592 .900$ \\
\hline 6 & 111 & 370 & 480 & 44 & $\mathrm{Rp} 72.841 .500$ \\
\hline 7 & 83 & 376 & 488 & 45 & $\mathrm{Rp} 73.418 .700$ \\
\hline 8 & 0 & 382 & 496 & 29 & $\mathrm{Rp} 70.510 .400$ \\
\hline 9 & 0 & 389 & 504 & 24 & $\mathrm{Rp} 71.059 .100$ \\
\hline 10 & 1 & 395 & 513 & 33 & $\mathrm{Rp} 73.426 .200$ \\
\hline 11 & 2 & 402 & 521 & 42 & $\mathrm{Rp} 75.814 .400$ \\
\hline 12 & 3 & 408 & 529 & 37 & $\operatorname{Rp} 76.289 .100$ \\
\hline
\end{tabular}

Permintaan yang tidak dapat diproduksi dengan kapasitas reguler eksisting dapat diproduksi dengan tiga alternatif, yakni dengan menggunakan over time resource, menggunakan tenaga kerja harian/buruh harian, out sourcing produk/ sub kontrak produksi dan perekrutan tenaga kerja baru. Total throughput yang diperoleh jika produk yang tidak dapat diproduksi pada kapasitas reguler diproduksi dengan penambahan resource dari alternatif yang diusulkan seperti pada Tabel VII.

TABEL VIII

Total THROUGHPUT DENGAN PENAMBAHAN KAPASITAS ALTERNATIF

\begin{tabular}{cc}
\multicolumn{2}{c}{ ALTERNATIF } \\
\hline Metode & Rp 1.017 .694 .600 \\
\hline Over Time & Rp 1.003 .644 .100 \\
\hline Out Sourcing tenaga kerja &
\end{tabular}




\begin{tabular}{ccc}
\hline Produk Sub Kontrak & $\mathrm{Rp}$ & 941.447 .600 \\
\hline Perekrutan Tenaga kerja Baru & $\mathrm{Rp}$ & 1.049 .366 .100 \\
\hline $\begin{array}{c}\text { Perekrutan Tenaga kerja Baru } \\
\text { dan Jam Over Time }\end{array}$ & $\mathrm{Rp}$ & 1.056 .763 .100 \\
\hline
\end{tabular}

\section{PEMBAhasan}

Kondisi bottleneck terjadi apabila selisih antara kapasitas resource tersedia dengan kebutuhan kapasitas resource bernilai negatif. Sebagian besar stasiun kerja pada seluruh periode mengalami kondisi bottleneck. Kondisi bottleneck membuat tidak semua produk dapat diproduksi pada resource reguler.

Eksploitasi constraints dilakukan dengan melakukan perhitungan waktu baku. Waktu baku hasil pengukuran digunakan sebagai acuan waktu proses. Eksploitasi constraints yang ada belum bisa mengatasi kondisi bottleneck resource. Pada aturan TOC, jika kondisi constraints tidak dapat dieksploitasi dan disubordinasi kebijakan perubahan untuk melakukan penambahan elemen dalam sistem dapat dilakukan. Resource yang menjadi constraints adalah kapasitas tenaga kerja (man hours).

Proses produksi ke empat jenis produk melalui proses di setiap stasiun kerja. Produk diproses secara berurutan dari stasiun kerja satu sampai stasiun kerja empat. Ketidakseimbangan kapasitas antar stasiun kerja menimbulkan penumpukan barang work in process pada stasiun kerja tertentu. Stasiun kerja yang menjadi buffer of constraints adalah stasiun kerja 3. Langkah penambahan kapasitas resource pada stasiun kerja 3 akan menimbulkan masalah baru apabila kapasitas resource pada stasiun kerja lainnya tidak diseimbangkan.

Untuk meningkatkan keuntungan perusahaan dengan keterbatasan resource maka dilakukan pengoptimalan resource reguler untuk mencapai nilai throughput maksimal. Nilai throughput maksimal didapat dengan memilih produk yang akan diproduksi pada kapasitas resource reguler yang tersedia. Penggunaan resource akan optimal untuk menghasilkan throughput yang maksimal jika produk A-102 dan A-103 menjadi prioritas untuk dipenuhi. Sedangkan produk A-101 dan A104 akan dipenuhi apabila kapasitas resource masih tersedia setelah seluruh demand A-102 dan A-103 terpenuhi.

Kondisi bottleneck dapat berpotensi memberikan kerugian senilai Rp 281.379.000 yang disebabkan oleh tidak terpenuhinya demand produk A-101 dan A-104. Selain kerugian finansial langsung akibat lost sales, kerugian akibat kehilangan konsumen perlu dipertimbangkan.
Penggunaan alternatif resource jam over time memberikan nilai throughput sebesar $\mathrm{Rp}$ 1.017.694.600 atau peningkatan $17,88 \%$ dari titik optimal pada kapasitas regular. Kapasitas alternatif resource dari jam over time belum bisa memenuhi seluruh kekurangan resource, sehingga masih terdapat demand yang belum dapat dipenuhi. Selain itu, penggunaan jam kerja over time yang tinggi untuk beberapa periode berturutturut akan melanggar aturan ketenagakerjaan. Namun alternatif ini memiliki kelebihan yaitu mudah dikoordinasikan dan produk yang dihasilkan sesuai dengan standar perusahaan.

Alternatif pemenuhan kekurangan resource dengan menggunakan sumber daya eksternal perusahaan dapat dilakukan dengan menggunakan buruh harian lepas, atau melalui sub kontrak (produk diperoduksi oleh perusahaan lain).

Penambahan kapasitas resource menggunakan alternatif dari tenaga kerja out sourcing harian atau buruh harian lepas akan memberikan total Rp 1.003.644.100 atau peningkatan 16,25\% dari titik optimal pada kapasitas regular. Nilai throughput lebih kecil dibandingkan dengan penggunaan jam over time dikarenakan penggunaan tenaga kerja/buruh harian mengeluarkan biaya tambahan yang lebih besar, adanya biaya makan, biaya lepas dan upah dibayarkan berdasarkan banyaknya produk bukan pada jumlah jam kerja. Dibandingkan dengan over time dan tenaga kerja harian, penggunaan alternatif sub kontrak produksi memberikan nilai throughput terkecil, hanya memberikan peningkatan $9,04 \%$ dari throughput pada kapasitas regular.

Penambahan kapasitas man hours dengan penambahan tenaga kerja reguler/operator produksi regular dapat mengatasi kekurangan kapasitas dan meningkatakn throughput perusahaan, namun juga menambah beban fix cost perusahaan. Penambahan tenaga kerja membuat beban kerja lebih stabil dan berdampak pada konsistensi pengerjaan produk. Peningkatan kapasitas man hours dengan perekrutan tenaga kerja/operator produksi dapat mengatasi masalah bottleneck. Perbaikan sistem dengan peningkatan kapasitas resource regular dilakukan dengan menambahkan 6 tenaga kerja/operator produksi, yaitu 1 orang pada SK-1, 1 orang pada SK-2, 3 orang pada SK-3 dan 1 orang pada SK-4.

Peningkatan kapasitas produksi dengan menambahkan 6 tenaga kerja/operator produksi tetap akan memeberikan kondisi bottleneck pada stasiun kerja 1 dan 4 pada periode 8, 9, 10 dan 12. Kondisi bottleneck ini dapat diatasi dengan menggunakan resource over time. Komposisi penambahan tenaga kerja ditentukan dengan mempertimbangkan fix cost yang paling minimum 
namun dapat memenuhi seluruh kebutuhan kapasitas.

Pada kondisi penambahan kapasitas regular, dan jika produk yang tidak dapat dipenuhi pada periode $8,9,10$ dan 12 diabaikan akan memberikan nilai throughput sebesar $\mathrm{Rp}$ 1.049.366.100, dengan peningkatan $21,54 \%$ dari nilai throughput pada kapasitas regular eksisting. Jika kekurangan resource dipenuhi dengan menggunakan kapasitas over time nilai throughput menjadi Rp 1.056.763.100 atau $22,40 \%$ dari nilai throughput pada kapasitas eksisting. Penggunaan kapasitas over time pada alternatif ini masih di dalam batasan aturan ketenagakerjaan. Alternatif ini tidak hanya menyelesaikan permasalahan pemenuhan demand tetapi juga perbaikan kapasitas internal eksisting.

\section{KESIMPULAN}

Setiap sistem memiliki keterbatasan (constraints) dalam mencapai titik throughput maksimal. Identifikasi elemen-elemen yang menjadi constraints dan buffer perlu dilakukan. Proses identifikasi, eksploitasi, subordinasi dan evaluasi constraints adalah proses yang tidak pernah berhenti, layaknya sebuh roda PDCA (plan-do-check-action). Penelitian ini menggunakan pendekatan TOC untuk menganalisis sistem produksi PT XYZ. Penerapan aplikasi TOC di PT XYZ hanya dilakukan pada bagian produksi. Pencarian solusi pada pendekatan TOC dikembangkan menggunakan metode lain yang sesuai. Penelitian ini mengembangkan metode pemecahan masalah dengan programa linier. Metode lain yang dapat digunakan seperti metode penjadwalan ataupun kesetimbangan lintasan produksi (line balancing).

Hasil pengolahan data disimpulkan sumber daya (resource) yang menjadi kendala (constraints) adalah jumlah tenaga kerja produksi atau operator (man power). Jumlah tenaga kerja yang kurang menyebabkan jumlah jam kerja yang dibutuhkan tidak mencekupi, dan terjadi bottleneck pada lintasan produksi. Throughput produksi yang dapat dicapai dengan mengoptimalkan sumber daya eksisting (resources regular) adalah $\mathrm{Rp}$ 819.148.490. Produk yang memberikan troughput maksimal adalah produk A-102 dan A-103. Nilai throughput yang dapat diperoleh pada kapasitas eksisting dari total demand yang ada adalah $74.43 \%$. Untuk memenuhi seluruh demand dikembangkan beberapa alternatif solusi. Alternatif solusi peningkatan kapasitas produksi yang memberikan nilai throughput maksimal dibandingkan dengan alternatif lain yang dikembangkan adalah penambahan jumlah tenaga kerja/operator produksi.

\section{REFERENSI}

[1] Sipper, D. dan Bulfin R., Production: Planning, Control and Intregration, New York: Mc. Graw Hill, 1998.

[2] Şimşit, Zeynep Tuğce, Günay, Noyan Sebla, dan Vayvay Ozalp, "Theory of Constraints: A Literature Review," Science direct-Social and Behavioral Sciences, vol. 150, pp. 930 - 936, 2014.

[3] Aguliar-Escobar, V.G., Garindo-Vega, P., and Zamora, "Applying the theory of constraints to the logistics service of medical records of a hospital," European Research on Management and Business Economics, vol, 22, pp. 139-146, Sep. 2015.

[4] Verma, R., "Management Science, Theory of Constraints/Optimized Production Technology and Local Optimization," Elsivier Science - Journal Management Science, vol 25 (2), pp. 189-200, 1997.

[5] Contas, J., Ponte, B., Fuente, D., Pino, R., dan Puche, J., "Applying Goldratt's Theory of Constraints to Reduce the Bullwhip Effect Trough Agent-Based Modeling," Science Direct - Expert Systems with Applications, 2014.

[6] Gunadi, "Aplikasi Theory Of Constraints pada Perusahaan Pengiriman (Studi Kasus PT Nusa Cargo)," Jurnal Ekonomi Sekolah Tinggi Ilmu Ekonomi Indonesia (STEI), Jakarta, 2014.

[7] Dettmer, H. dan Goldratt's, Theory of Constraint: A system Approach to Continous Improvement, Milwaukee: ASQC, 1997.

[8] Okutmus, E., Kahveci , A., and Kartašova, J., "Using theory of constraints for reaching optimal product mix: An a application in the furniture sector," Science directIntellectual Economics, vol. 9, pp.138-149, Feb 2016.

[9] Makridakis, Wheelwright, and Hyndman. Forecasting Method and Applications, New Delhi: Wiley, 2015.

[10] Wignjosoebroto, S., Ergonomi, Studi Gerak \& waktu, Jakarta: Penerbit Guna widya, 1995.

[11] Reid, R. A., "Applying the TOC five-step focusing process in the service sector: A banking subsystem," Managing Service Quality, vol. 17(2), pp. 209-234, 2007.

[12] Šukalová,Viera dan Ceniga, Pavel, "Application of The Theory of Constraints Instrument in The Enterprise Distribution System," in Proc. Procedia Economics and Finance, 2015, paper Vol. 23 pp. $134-139$.

[13] Gupta, M., "Constraints management-recent advances and practices," International Journal of Production Research, vol. 41(4), pp. 647-659, 2003. 